(C) А.М. Белов, О.Ю. Галинская

\title{
ДЕЯТЕЛЬНОСТЬ МЕСТНЫХ ВЛАСТЕЙ ПО БОРЬБЕ С ЭПИДЕМИЯМИ ВО ВТОРОЙ ПОЛОВИНЕ ХІХ - НАЧАЛЕ ХХ ВЕКА (НА МАТЕРИАЛАХ КОСТРОМСКОЙ ГУБЕРНИИ)*
}

\begin{abstract}
После отмень крепостного права приток населения в города, в т.ч. в Кострому, привел к проблемам перенаселенности губернского иентра и несоответствия существующей инфраструктуры (жилищной, транспортной, коммунальной) изменившейся численности жителей. Данная ситуация способствовала взрывному росту и распространению в Костроме заразных болезней, в том числе, массовых эпидемий холеры, тифа, оспь, скарлатины, следствием которых стала повышенная смертность среди костромичей, приводящая в некоторые годы к убыли населения губернского города.

В статье на материалах Костромской губернии, прежде всего, губернского центра, рассматривается общая эпидемиологическая обстановка с 70-х г2. $X I X$ века до начала XX века, а также основные направления совместной деятельности губернского правления и городских органов общественного управления по снижению эпидемиологической напряженности и профилактике массовых заболеваний в период капиталистической модернизации. В статье приведены статистические данные по Костромской губернии и губернскому центру, использованы отчеты Медицинского департамента Министерства внутренних дел за указанный период, материаль периодической печати, показана региональная специфика решения возникших проблем, учитывая, что Костромская губерния относилась к числу наиболее развитых промышленных губернии Российской Империи.
\end{abstract}

Ключевые слова: массовые эпидемии, эпидемиологическая обстановка, Костромская губерния, смертность, губернское правление, общественное управление, статистика

Ссылка при цитировании: Белов А.М., Галинская О.Ю. Деятельность местных властей по борьбе с эпидемиями во второй половине XIX - начале XX века (на материалах Костромской губернии) // Вестник антропологии, 2021. № 2. C. 128-143.

Белов Андрей Михайлович - д.и.н., профессор кафедры истории, Костромской государственный университет (156005, г. Кострома, ул. Дзержинского, д. 17). Эл. почта: belovi_1957@mail.ru

Галинская Оксана Юрьевна - аспирант кафедры истории, Костромской государственный университет (156005 Кострома, ул. Дзержинского, 17). Эл. почта: oknikitina@yandex.ru

* Статья написана при поддержке гранта РФФИ № 21-011-31820, рук. А.М. Белов. 
На протяжении тысячелетий человечество периодически сталкивается с эпидемиями. Борьба с ними имеет длительную, полную драматизма историю. Только в XXI в. мир испытал на себе эпидемии свиного и птичьего гриппа в 2009 г., лихорадки Эбола в 2014-2015 гг., а пандемия коронавируса, вспыхнувшая в 2019 г., еще какое-то время будет оставаться в новостных строках мировых СМИ. Все это заставляет искать новые способы не только борьбы, но и профилактики заразных заболеваний. В связи с этим представляет интерес опыт борьбы и профилактики эпидемий в Российской империи, где в период урбанизации в конце XIX - начале XX вв. произошел резкий скачок численности городского населения, что повлекло за собой массовое распространение заболеваний. Статья подготовлена на материалах Костромской губернии - типичной губернии Центральной России.

В изучаемый период Костромская губерния входила в состав Московского промышленного района. Рост экономики сопровождался увеличением численности городского населения, прежде всего, губернского центра. Население Костромы выросло с 28143 чел. в 1867 г. (Пирогов 1870: 8) до 68700 чел. в 1914 г. (Рашин 1956: 90-91). Несоответствие в губернском городе объектов коммунальной инфраструктуры, прежде всего, водопровода и канализации, возросшей численности населения привело к росту инфекционных болезней. Поэтому первоочередными становятся меры по созданию благоприятных санитарно-гигиенических условий проживания в городе и снижению эпидемиологической напряженности.

В работе использованы данные медицинских отчетов Министерства внутренних дел Российской империи 1879-1914 гг., ежегодные обзоры Костромской губернии приложения к всеподданейшим отчетам губернатора за 1870-1914 гг., локальные нормативно-правовые акты, материалы периодической печати, статистические данные Костромского губернского статистического комитета, отчеты Костромской городской Управы за указанный период. Медицинский департамент МВД ежегодно публиковал отчеты о состоянии народного здравия в Российской империи на основании предоставляемых данных губерний, которые включали в себя информацию по рождению и смертности, заболеваемости и причинам смертности (Отчет Медицинского департамента 1877). Отдельно публиковались данные по заразным и эпидемическим болезням. Отчеты включали в себя также разделы по врачебно-полицейскому надзору, ветеринарной и судебно-медицинской частям и др. Данные отчеты позволяли выявить районирование болезней, определить очаги заболеваний, предусмотреть возможный масштаб их распространения.

Региональная специфика по эпидемиологической ситуации в губернии представлена в материалах периодических изданий «Эпидемиологический листок», «Костромские Губернские Ведомости» - обзорах Костромской губернии, где в разделе «Народное здравие» отражались данные по медицинской части и отдельно по эпидемиям, имевшим место в отчетном году (Костромские губ. ведомости 1871). В отчетах Костромской городской Управы приводятся данные по перечню проводимых мероприятий, направленных на снижение эпидемиологической напряженности в губернском центре и понесенным затратам на их осуществление (Отчет за 1898 г. 1899).

В конце XIX - начале XX столетия в России показатели рождаемости были одними из самых высоких в Европе, но прирост населения был бы еще более значительным, если бы не показатели смертности. В России только в XIX в. было зарегистрировано пятнадцать эпидемий чумы, восемь эпидемий холеры (Васильев 1960: 6), а 
тифозные заболевания, оспа, дифтерия, корь, скарлатина регистрировались каждый год. Поэтому высокие показатели смертности были вызваны, в том числе, массовым распространением заразных или заразно-повальных (эпидемических) заболеваний, к которым в разное время относили различные болезни. Так, если в 70-е гг. XIX в. к их числу относились оспа, корь, скарлатина, дифтерия, грипп, коклюш, все виды тифов, сифилис, сибирская язва, то в 1914 г. насчитывалось 32 вида заразных заболеваний (Отчет Медицинского департамента 1878; Городовое положение 1870: 13).

На протяжении 80-х гг. XIX в. в России заразно-повальные болезни по заболеваемости и смертности занимали первое место. В 1882 г. из числа 3509171 больных, по которым была опредлена форма заболевания, 1257049 чел. $(35,8 \%)$ имели болезни заразно-повального характера, при этом именно эти заболевания стали причиной смерти у 126573 (10\%) из них (Отчет Медицинского департамента 1884: 4-8). В 1886 г. из 10624313 чел. с зарегистрированной формой заболевания число заболевших заразными болезнями составило 1840708 чел. $(17,3 \%)$, из них умерло 162759 чел. (8,8\%) (Отчет Медицинского департамента 1891: 34-37). В начале ХХ в. эпидемическая напряженность в стране оставалась напряженной. При снижении удельного веса заразных заболеваний в общей структуре болезней населения в данный период, в абсолютных значениях число больных продолжало расти. В общей массе зарегистрированных заболеваний заразные болезни составили в 1911 г. -14 754853 чел. или 17\% (Отчет о состоянии 1913: V), а в 1914 г. - 14538028 чел. или 16\% (Отчет о состоянии 1914: VI).

При этом реальные показатели значительно отличались от официальных данных в связи с тем, что они указывались только на основании случаев с зарегистрированной формой заболевания, а учитывая невысокий процент обращавшихся за врачебной помощью, значение указанных показателей не соответствовало реальной эпидемиологической ситуации в стране. Например, по данным отчета Медицинского департамента за 1884 г. врачебной помощью в стране в течение года воспользовалось лишь 11538555 чел., что составило 12\% от всего населения Российской империи (96 052071 чел.), из этого числа обратившихся только для 4757881 чел. (41\%) была определена форма заболевания (Отчет Медицинского департамента 1887: 1-3).

С увеличением на местах численности врачей возрастала и доступность оказания врачебной помощи, что выражалось в увеличении регистрируемых форм заболеваний. При увеличении числа обращавшихся за врачебной помощью менялась и общая картина заболеваемости по стране (Таблица 1).

Таблица 1

Численность зарегистрированных больных в к. XIX - начале XX вв.

\begin{tabular}{c|c|c}
\hline Год & Абсолютные значения & На 1000 человек \\
\hline 1896 & 35790596 & 287 \\
\hdashline 1898 & 42125892 & 327 \\
\hline 1900 & 46914863 & 352 \\
\hline 1902 & 52378558 & 361 \\
\hline 1904 & 56835226 & 399 \\
\hline
\end{tabular}


Таблица 1 (продолжение)

\begin{tabular}{c|c|c}
\hline Год & Абсолютные значения & На 1000 человек \\
\hline 1906 & 65773550 & 447 \\
1910 & 83311256 & 591 \\
1912 & 90875669 & 621 \\
\hline 1914 & 90862675 & 604 \\
\hline
\end{tabular}

* (Отчет о состоянии народного здравия 1908: 6, 12, 51; Отчет о состоянии народного здравия 1914).

В Костромской губернии в указанный период количество больных заразными заболеваниями росло, как и в других российских городах. В 1900 г. число заболевших заразными болезнями в Костромской губернии составило 158233 чел. (Обзор губернии 1901: 21), в 1910 г. - 167866 чел. (Обзор губернии 1911: 28-29), в 1913 г. 183837 чел. (Обзор Костромской губернии 1914: 34).

Рост числа заболевших объяснялся, в том числе, налаженным учетом и повышением доступности врачебной помощи. Так, за 1888 г. была оказана «помощь со стороны врачебного персонала 351301 больным, из числа коих 106951 человек страдали заразными болезнями» (Обзор Костромской губернии 1892: 19), а в 1914 г. «больных острозаразыми болезнями, подлежавших наблюдению врачей и фельдшеров» было 163758 чел. (Обзор Костромской губернии 1914: 34). Учитывая, что число обратившихся за врачебной помощью в губернии составило в 1914 г. 1515681 чел. (Отчет о состоянии народного здравия 1916 (приложения): 4-5), доля заболевших заразными болезнями в губернии составила 10,8\%.

При анализе причин смертности населения данные тоже были неполными в связи с тем, что статистика с обязательным удостоверением причин смерти врачами велась лишь в ряде крупных российских городов - Санкт-Петербурге, Москве и Одессе. В виду того, что в губерниях Европейской России охват врачебной помощью был не повсеместный, с 1891 г. вводится регистрация умерших от остро-заразных болезней по метрическим книгам.

Впервые в Российской Империи подобная практика была применена в Костромской губернии, когда в 1888 г. «приходские священники, по повелению преосвященного, вошедшего в согласие с губернатором, ежемесячно делали выборку из метрических книг об умерших от эпидемических болезней» (Айвазов 1913: 73-74), а затем передавали эти сведения полиции. Этот опыт был отражен во Всеподданейшем отчете костромского губернатора В.В. Калачева за 1888 год и «Государю Императору Всемилостивейше благоугодно было признать означенный способ собирания сведений о заразных болезнях чрез приходских священников мерою весьма полезною...» (Белов 2009: 80; Рашин 1956: 312).

Синод в 1889 г. вменил духовенству всех епархий Империи, начиная с 1890 г., в течение трех лет проводить ежемесячную регистрацию смертности от заразных болезней по метрическим записям на основании опыта духовенства Костромской губернии. Впоследствии в 1890 г. этот способ определения смертности по данным метрических книг также был отражен в циркулярном предложении Министра внутренних дел губернаторам (Рашин 1956: 74). И хотя со стороны духовенства существовали неточности в определении причин смерти, все же эти данные были бо- 
лее полными в отличие от данных врачебных управлений, которые регистрировали умерших из числа обращавшихся за врачебной помощью.

Значительной была в общей структуре и доля заразных болезней при анализе причин смертности. В Костромской губернии в 1880 г. из 51291 чел. от заразных болезней скончалось 14117 чел. (27,5\%) (Отчет Медицинского департамента 1884: 6), в 1906 г. - 15826 чел. (15\%) (Отчет о состоянии народного здравия 1908: 32-45).

В Костроме, как наиболее развитом и населенном центре губернии, заразные болезни стали причиной смерти в 1880 г. у 183 чел. из 1164 умерших (Отчет Медицинского департамента 1882: 10), в 1883 г. - у 162 чел. из 988 умерших, то есть в в 16\% случаях (Отчет Медицинского департамента 1886: 16), в 1891 г. этот показатель составил 9\% (115 чел. из 1231 чел.) (Отчет Медицинского департамента 1894: 12-13), в 1892 г. - 18\% (216 чел. из 1231 чел.) (Отчет Медицинского департамента 1896: 1213). Поэтому в исследуемый период были годы, когда по отношению к рождаемости смертность была выше, что приводило к убыли населения. Например, в 1880 г. по данным городового врача И.С. Иванова в Костроме образовалась убыль населения в 47 человек - «вся убыль падает на население мужскаго пола, в котором число родившихся было менее числа умерших на 54 человека. В женском населении была прибыль в 7 человек» (Иванов 1883: 6-7).

Прежде всего, в группе риска находились дети 1 года до 5 лет. Особо высокой была младенческая смертность: из 1145 чел. 390 чел. были дети на первом году жизни (34\%) (Отчет Медицинского департамента 1891: 20-21), а в 1892 г. 454 младенца (37\%) (Отчет Медицинского департамента 1896: 12).

В медицинском отчете за 1877 г. указывалось, что «детские болезни составляют две трети всех лихорадочных заразных болезней» (Отчет Медицинского департамента 1878: 6). В исследуемый период детские инфекции - дифтерия, коклюш, корь, скарлатина или «горлохват» регистрировались почти ежегодно, часто принимая форму эпидемий. Как отмечал в своем обзоре городовой врач И.С. Иванов, также руководивший сельской лечебницей при Костромском женском Богоявленском монастыре с 1874 по 1880 гг, ему «постоянно приходилось слышать о той или другой эпидемии, свирепствовавшей в Костроме, особенно об эпидемиях, поражающих преимущественно детей» (Пирогов 1881: 117).

Так, в 1876 г. в Костроме коклюш «принял форму эпидемии и притом в довольно больших размерах» (Отчет Медицинского департамента 1877: 14), а уже в 1880 г. Костромская губерния относилась к числу наиболее пострадавших российских губерний от скарлатины (Отчет Медицинского департамента 1882: 40). (Таблица 2).

Не менее опасной была корь. В отчете за 1879 г. медицинского департамента МВД отмечалось: «Корь менее других останавливает на себе внимание врачей и родителей, а потому... власти узнают о ней только в случаях особой злокачественности припадков и сильного повального распространения» (Отчет Медицинского департамента 1881: 407). В 1881 г. в Костромской губернии было зафиксировано максимальное число заболевших корью в Российской Империи - 4743 чел., далее следовали Киевская губерния с числом заболевших 3372 чел. и Гродненская губерния - 2343 чел. (Отчет Медицинского департамента 1884: 97).

Одной из серьезных заразных болезней в Российской Империи была оспа. Несмотря на то, что в России первый опыт вакцинации был произведен в 1801 г. и уже в 1804 г. прививка оспы проводилась в 19 губерниях России, оспопрививание не везде 
было успешным, прежде всего, это касалось тех губерний, где проживало большое количество раскольников, к которым относилась и Костромская губерния.

Таблица 2 Данные по наибольшему числу заболевших скарлатиной в губерниях 1880 г.

\begin{tabular}{l|c|c}
\hline Губерния & Число заболевших & Число умерших \\
\hline Лифляндская & 2266 & 303 \\
\hdashline Пензенская & 1671 & 359 \\
\hdashline Саратовская & 1436 & 410 \\
\hdashline Тамбовская & 1261 & 284 \\
\hline Костромская & 1000 & 186 \\
\hline
\end{tabular}

В Костромской губернии эпидемия оспы распространилась в 1874 г. (Отчет Медицинского департамента 1877: 5). В основном этой болезни подвергались дети, в том числе и те, кому ранее было сделано предохранительное оспопрививание (Там же: 6). Поэтому на протяжении изучаемого периода Костромская губерния занимает первые строки официальных медицинских отчетов по числу заболевших и умерших от оспы. В 1877 г. в Костромской губернии наблюдалось максимальное число заболевших оспой в России - 1060 чел. В 1879 году оспа наблюдалась «так же, как и в предшествующие годы. Эпидемия оспы оказалась преобладающею на протяжении p. Волги < .. > по среднему течению Волги она была в губерниях: Костромской и Нижегородской» (Отчет Медицинского департамента 1881: 16). Всего в Костромской губернии число заболевших составило 3661 чел. (Там же: 19). Наиболее вероятной причиной появления и развития оспы, по отзывам врачей, «заключалась в дурных условиях крестьянских жилищ в гигиеническом отношении в связи с дурным уходом за больными, в близком соприкосновении больных детей со здоровыми, нередко исполнявшими обязанности нянек в рабочее время» (Обзор Костромской губернии 1881). При этом со слов городового врача «болезнь эта появляясь ежегодно, составляла как бы продолжение свирепствовавшей в городе в 1874 году оспы, имевший весьма интенсивный характер...» (Там же).

Наряду с ежегодно регистрируемыми заразными заболеваниями, особо опасными были годы, на которые приходились эпидемии холеры. В течение XIX в. холера наблюдалась в России 8 раз (1823, 1829, 1830, 1837, 1847, 1852, 1865 и 1892 гг.) (Васильев, Сегал 1960: 249). После каждого холерного «вторжения» следовало несколько лет, когда болезнь держалась в разных районах страны. Костромская губерния была в центре Российской империи, поэтому занос холеры, как правило, происходил по Волге через крупные центры торговли и распределение грузов: с низовьев через Нижний Новгород, либо через находившийся выше по течению Рыбинск. Сезонная динамика заболеваемости холерой приходилась, как правило, на лето и начало осени.

Впервые холера появилась в пределах России в 1823 г. (Там же: 252), а в Костроме первые случаи заболевания были зафиксированы в 1830 г. В работе П.Ф. Островского указывается, что «страшна была неожиданная весть о болезни, внезапно поражавшей людей смертностью и дотоле не известной в России...» (Островский 1964: 142). Затем на протяжении первой половины XIX в. болезнь повторялась в 1831 г., 
1848 г. «похитившая не малое число ее жителей от среды живых, понесших чрез это потери не возвратныя» (Там же: 164) и Холерная эпидемия 1853 г., несмотря на широкое распространение, была менее интенсивна, чем эпидемия 1848 г., но Костромская губерния оказалась в числе наиболее пострадавших. По официальным данным в Костромской губернии число заболевших холерой составляло 10212 чел., а умерших - 5480 чел., но по данным городского врача Костромы И.С. Иванова, только по метрикам число умерших составляло 12552 чел., следовательно, заболевших было еще больше (Иванов 1885: 18). В исследуемый период холера продолжала оставаться наиболее опасной заразной болезнью. Несмотря на существующий опыт по борьбе с холерными эпидемиями в 1830-1853 гг., среди специалистов не было выработано единого мнения на причины, способствующие возникновению и распространению болезни. В 1870-е гг. врачи обратили внимание, что эпидемии не могут объясняться только климатическими или почвенными причинами, что существует и социальный аспект данного явления. Учитывая низкую эффективность карантинных мер, власти от них постепенно отказывались, но новых мер в этот период выработано не было. Положительным результатом научной дискуссии стало понимание необходимости санитарного оздоровления населенных мест, устройство водоснабжения и регулярный вывоз нечистот. В 1870 г., в период очередного подъема эпидемии холеры в России, болезнью была поражена 31 губерния. В Костромской губернии в 1870 г. наблюдались единичные случаи болезни в Юрьевце, куда холера была занесена из Н. Новгорода, но широкого распространения она не получила (Материалы для статистики 1881). В полной мере болезнь проявила себя на следующий год.

В начале 1871 г. болезнь появилась в Петербурге и Москве, а с наступлением весны она стала распространяться по губерниям страны. В Костроме эпидемия началась в июне 1871 г., когда одного заболевшего холерой сняли с парохода, пришедшего из Рыбинска. Как указывалось в «Эпидемиологическом листке» за 1871 г., «холерный яд... скоро достиг Рыбинска и Ярославля, где вследствие скопления рабочих эпидемия быстро приняла серьезные размеры и стала распространяться по волжскому пути» (Архангельский 1871a: 13). В связи с этим в Рыбинске возникла паника «большинство чернорабочих, чувствуя первый припадок холеры, Христом-Богом просили не отправлять их в больницы, а дать умереть лучше на вольном воздухе $<\ldots>$ более 8000 человек < ..> ушли на родину, испугавшись эпидемии» (Архангельский 1871b: 10), тем самым став разносчиками болезни.

21 июня 1871 г. в земскую больницу Костромы был помещен заразившийся холерой на лесной пристани р. Волги мещанин Буйского уезда, затем заболела прислуга больницы, и с 28 июня болезнь стала быстро распространяться по городу. «Люди, малообеспеченные, изнуренные непосильным трудом или болезнями, сильно расположены к заболеванию холерой. Поэтому-то холера особенно резко обнаруживалась в бедных классах населения г. Костромы - между чернорабочими, ремесленниками, инвалидными солдатами, арестантами и проч.» (Иванов 1885: 42-43) - отмечал в своем обзоре холерных эпидемий на территории Костромской губернии городовой врач И.С. Иванов. С августа в Костроме «эпидемия проявилась еще в сильнейшей степени, поражая значительное число не только бедных, но и зажиточных людей, тщательно себя оберегавших» (Обзор Костромской губ. 1871).

В отчете губернатора указывается, что причины, способствующие развитию болезни, видели в погодно-климатических условиях и употребляемой пище: «появ- 
ление первых после весеннего времени, и довольно сильных жаров, потребление в Петров пост легко разстраивающих желудок, овощей - луку, капусты и картофеля, а после поста - резкая перемена в пище» (Там же).

Только к 19 сентября эпидемия в городе стала стихать. В ежегодном Всеподданейшем отчете костромского губернатора за 1871 г. указывается, что наиболее пострадали от холеры жители Костромы, Кинешмы и уездов: Костромского, Нерехтского, Буйского и Юрьевецкого. Всех заболевших по губернии насчитывалось 4075 чел., из которых 1363 чел. умерло. Эпидемия холеры 1871 г. стала серьезным испытанием для городских органов общественного управления - городской Думы и городской Управы, которые, в соответствии с принятым в 1870 г. Городовым положением, осуществляли в городе врачебно-полицейский контроль.

Координацию противохолерных мероприятий в губернии осуществлял Губернский Комитет общественного здравия, созданный в 1852 г. на основании указа Сената «О правилах учреждения и действий комитетов общественного здравия» от 24 января 1852 г. с целью «охранения народного здравия, ... для устранения всего того, что угрожает здравию, и принятия единообразных мер к пресечению болезней эпидемических и эпизоотических» (Отчет о состоянии 1915: 1-3). Комитеты общественного здравия представляли собой коллегиальные органы надзора за эпидемиологической обстановкой в губернии. В состав комитета, кроме возглавлявшего его губернатора, входили должностные лица губернии, инспектор врачебной управы, Городской голова, городовой врач, полицмейстер, представитель духовенства. Деятельность Комитетов общественного здравия состояла, главным образом, в принятии санитарных мер во время возникновения эпидемий. За неимением средств их деятельность в остальное время ограничивалась просветительской работой.

В 1871 г. по случаю появления холеры в обеих столицах и в ряде других городов, Комитет общественного здравия был созван еще до появления болезни в губернии. Комитетом были выработаны меры для предупреждения появления холеры в губернии, преследовавшие, главным образом, удаление с улиц, дворов и из жилых помещений нечистот, и повсеместную дезинфекцию. Городской Управе было поручено в трехнедельный срок привести в порядок площади, частные дома, и особенно грязные улицы, произвести медико-полицейский осмотр торговых и промышленных заведений, тюрем, казарм, больниц, фабрик и школ, причем особое внимание обращалось на устройство и чистоту ретирадных мест. Предполагалось также устройство временных больниц для заболевающих холерою на пароходах, и в этой связи подбор квартир, а также информирование жителей о важности использования в быту дезинфицирующих средств, очистки помойных ям и ретирадных мест.

В Костроме вопросы дезинфекции приобретали особое значение, учитывая скученность проживания во многих районах, высокая степень передвижения населения через губернский центр, а также большое количество отходников и интенсивность речного сообщения (по ее притокам - рекам Кострома, Унжа, Ветлуга и др.).

В случае появления в стране эпидемии, в Костроме на берегу Волги устанавливался «санитарный надзор». Выявленные больные не допускались в город, а помещались в специально созданные на берегу Волги бараки (Обзор Костромской губернии 1871). По требованию городской Думы в городе при Управе определялся необходимый запас дезинфицирующих средств для выдачи неимущему населению бесплатно. Дезинфекции должны были подвергаться не только отхожие места и по- 
мойные ямы, но и дома, квартиры частных лиц, помещения общественных учреждений, публичных заведений и др.

Помимо указанного в начале июля 1871 г. в печати публикуется объявление о появлении холеры в Костроме. По предписанию Комитета общественного здравия домовладельцы обязаны были «нечистоты ретирад и помойных ям вывозить за город в отведенные для сего места, и строго запрещается сваливать их на берегу Волги» (Костромские Губернские Ведомости 1871: 192). Требования Комитета общественного здравия легли в основу постановлений городской Думы обязательных для исполнения (Обзор Костромской губернии 1893: 6).

Для жителей города была составлена инструкция с описанием симптомов болезни и описанием необходимых действий в случае заболевания до появления врача. Также было принято решение о бесплатном лечении в городской больнице больных всех сословий.

Для организации контроля численности заболевших город был разделен на врачебные участки, во главе которых стояли врачи: И.В. Спасокукоцкий, Р.Ф. Рудзкий, И.А. Зитовецкий, М.Г. Бекаревич, Л.Д. Данилов, И.Н. Персиянцев, Ф.К. Гожов, М.А. Невский, В.В. Дримпельман (Костромские Губернские Ведомости 1871: 192). В помощь врачам в каждый из участков были назначены попечители, в обязанности которых входил обязательный обход домов с целью выявления заболевших и сообщения о них врачам. В период обострения заболевания из-за недостатка врачебного персонала попечителям были розданы противохолерные аптечки для оказания первой помощи больным до прибытия врача. Участие губернского земства в мероприятиях по прекращению холеры в Костроме выразилось в открытии холерного отделения, в котором получили врачебную помощь 259 человек (Обзор Костромской губернии 1871).

На заседании Костромской городской Думы в августе 1871 г. в связи с повышенной нагрузкой на врачей в период эпидемии городское общественное управление назначило дополнительное специальное вознаграждение: для врачей, состоящих на службе, оно составило 30 рублей в месяц, а для вольнопрактикующих врачей 50 рублей в месяц. Для покупки медикаментов был открыт кредит в 200 рублей (Там же). Для организации своевременной доставки больных Дума приняла решение о найме 24 ночных извозчиков, которые были рассредоточены по всему городу с целью оперативной доставки к врачу, священнику или в больницу.

Для пресечения разного рода слухов и распространения в городе паники, в «Костромских Губернских ведомостях» еженедельно публиковались сводки «о числе больных, одержимых холерой по Костромской губернии» (Костромские Губернские Ведомости 1871, № 34: 244).

Существенным вкладом в борьбу с холерой стало создание в Костроме водопровода, строительство которого было начато в августе 1869 г. по предписанию Костромского губернского правления. Водопровод был пущен в эксплуатацию в сентябре 1871 г. (Рашин 1956: 26). Учитывая, что протяженность водопровода в городе была небольшой, и основная доставка воды населению продолжала осуществляться бочками, Думой уделяется особое внимание чистоте бочек (Костромские Губернские Ведомости 1871 №27: 240). В этот период еще не проводится полноценный контроль за продуктами питания, но Комитет общественного здравия предписал полиции «не допускать продажи незрелых фруктов» (там же).

Повышенное внимание уделялось захоронению умерших от болезни. В целях борьбы с холерой полиции было предписано следить за погребением умерших, чьи 
могилы должны были заливаться известью. Тем не менее на следующий год (1872) по Костромской губернии отмечались единичные случаи заболевания холерой, но она не приняла массового характера.

Из других мер борьбы с эпидемией холеры, владельцам фабрик и заводов вменялся в обязанность санитарный надзор за рабочими, а в случае эпидемии на них возлагалось обустройство холерных бараков на фабричных дворах. В случае выявления больных среди рабочих «строго наблюдать, чтобы они не были разссчитываемы и отпускаемы в деревни, как это нередко делается в настоящее время» (Обязательные постановления 1897: 27). В виду того, что холера в Костромскую губернию заносилась почти исключительно лицами, прибывавшими по Волге, содержатели пристаней должны были проветривать и очищать помещений дезинфицирующими средствами после каждого отбытия парохода, а в помещениях для пассажиров 3 раза в неделю стены в уровень роста человека и полы должны были обрабатываться кипятком с мылом (Там же: 26). Для проведения дезинфицирующих работ владельцы трактиров и гостиниц должны были в своих заведениях мягкую мебель или заменить на деревянную или же обить «клеенкою и притом совершенно гладко» (Там же: 22). Торговцам была запрещена продажа «белья, носильного платья и постельных принадлежностей, бывших в употреблении у больных заразительными болезнями (оспой, скарлатиной, тифом, холерой, дифтеритом и др.)» (Там же: 23).

Особо остро стоял вопрос контроля над нечистотами. В Костромской губернии существовала практика свозить в зимнее время нечистоты, хозяйственные отбросы и навоз на лед рек с тем расчетом, что весной все это будет унесено водой (Отчет Медицинского департамента 1887: 191). Органы общественного управления начали вести борьбу против этой практики. Помимо издания постановлений обязательных к исполнению, органы общественного управления занимались устройством ретирадных мест в местах массового скопления людей с целью предупреждения распространения заразных болезней. Первый общественный туалет в губернском центре появляется в Гостином дворе. В 1871 г. владельцам лавок в Гостином дворе г. Костромы вменялось «в непременную обязанность избрать места для устройства на них ретирадных мест и их устроить» (Обзор Костромской губернии 1915: 9). Вскоре здесь же появляется и первый ватер-клозет.

В Костроме городские органы общественного управления постоянно уделяли внимание поддержанию существующей водопроводной сети и дальнейшему ее развитию. Созданный в Костроме водопровод имел ряд существенных недостатков, прежде всего, отсутствие на нем фильтров. Это, в свою очередь, было одной из причин распространения заболеваний. В подготовленном для городской Думы докладе санитарной комиссии указывалось, что «за период 1893-1897 гг. смертность 32,2 на тысячу жителей, тогда как в английских городах - 16,4, в Норвегии 16,6, в Париже 18,3, в Берлине 19» (125 лет Костромскому водоканалу 1996: 40). В Костроме вопрос об улучшении качеств питьевой воды стал обсуждаться в 1898 г., когда Дума поручила городской Управе «снестись со специалистами или с специальными техническими конторами, которые бы указали способ улучшения воды в городе из реки Волги или из других источников, составили бы на это смету расходов» (Отчет Костромской Городской Управы 1899: 151). Предложения технических специалистов по фильтрам были отклонены в виду их высокой стоимости.

В то же время, с ростом городского населения необходимо было определиться с основным и дополнительным источниками воды для населения города. Существующий 
водоразбор не позволял покрывать все потребности растущего города. На заседании Думы в 1898 г. отмечалось, что «из существующего водопровода в некоторые дни не достает воды обывателям, в особенности... по субботам... в больнице губернского земства в этот день нельзя принимать в больницу больных, так как нельзя больным сделать, за недостатком воды, ванн» (125 лет Костромскому водоканалу 1996: 36-37).

Весной 1905 г. вода, взятая из буровой скважины в местности Якиманиха, «была подвергнута химическому анализу и признана годной для питья как лабораторией Феррейна, так и химико-бактериологическим институтом доктора Блюменталя» (Там же: 44). Оставалось только произвести расчеты по определению суточного количества воды, для чего были привлечены специалисты из Москвы. Таким образом, в городе помимо снабжения города волжской водой, был разработан альтернативный источник ключевой воды из района Якиманиха. В период с 1898 по 1909 гг. периодически поднимался вопрос об использовании фильтров на водопроводе и их эффективности, но установлены они были только в рамках мероприятий по празднованию 300-летия дома Романовых, широко проводившихся властью в Костроме в 1913 г.

В ХХ в. в Европейскую Россию холера вновь была занесена в 1904 г. и продержалась в стране до 1926 г. Значительное распространение болезнь получила с 1908 по 1910 гт., но в Костромской губернии рост заболевания пришелся на 1907-1910 гг. В 1907 г. Общее число пораженных холерой в губернии составило 277 чел., из них умерло 125 (Обзор Костромской губернии 1901: 42). Больше всего заболеваний было в губернском центре. Больные поступали из чайных, где были «добыты сведения, что все заболевшие пили сырую воду, в которой найдены были холерные вибрионы» (Обзор Костромской губернии 1908: 126). При эпидемии холеры в 1907 г. Кострома по опыту предыдущих лет была разделена на участковые санитарные попечительства, городской Управой были изданы правила организации деятельности участковых санитарных попечителей, а для жителей «вывешены на видных местах ...наставления о холере с указанием, как самому уберечься от заразы и не давать заразе распространяться на других» (Обзор Костромской губернии 1901: 42). В губернской земской больнице открыто заразное отделение для заболевших, также открыты дополнительная больница на 30 мест в доме Костромского уездного земства и приемный покой на 6 мест за рекой Волгой с целью устранения возможности распространения болезни при переправе через Волгу. При Костромской городской Управе было образовано осведомительное бюро, в котором была вся информация по эпидемическому состоянию в городе. Казанским округом путей сообщения на берегу Волги был открыт барак для холерных больных с пароходов и судов, проходящих через Кострому (Там же: 42). Несмотря на серьезные профилактические меры, принятые в 1907 г., эпидемия холеры повторилась и на следующий год. Причиной болезни в 1908 г. вновь стала сырая вода, а «наибольшее число заболеваний холерой было в местах, находящихся в антисанитарном состоянии: скученность построек, экономическая необеспеченность населения, теснота и грязь» (Отчет о состоянии народного здравия 1909: 131-132). Наряду с предпрнимаемыми мерами, аналогичными ранее, городской Управой жителям города была предложена бесплатная предохранительная прививка.

Таким образом, если проследить деятельность органов городского управления за исследуемый период, то можно выделить ряд этапов в организации работы по предупреждению и прекращению заразных болезней и, прежде всего, холеры.

С введением в 1870 г. Городового Положения и закреплением за городскими структурами управления вопросов санитарного контроля, начался постепенный пе- 
реход от разовых спонтанных действий, вызванных непосредственно эпидемиями, к осуществлению системных профилактических мер по благоустройству и оздоровлению городов, развитию в них постоянного санитарного надзора.

В период эпидемии 1871 г. действия городской Думы и Управы под контролем Комитета общественного здравия можно отнести еще к разовым экстренным мерам в период холерной эпидемии. Эти действия осуществлялась на основании предписаний Медицинского департамента в случае появления в губернии эпидемии: разделение города на участки во главе с врачом, составление и распространение информационных материалов санитарно-просветительского характера, организация круглосуточного контроля за эпидемией в городе, очистка улиц, помойных ям и отхожих мест, а также их дезинфекция, бесплатное распространение дезинфицирующих средств и необходимых медикаментов среди малоимущего населения, увеличение количества мест для заболевших в городских больницах, бесплатное лечение всех сословий (Варадинов 1862: 398-399).

Формирование системы врачебно-полицейского надзора в целях оздоровления Костромы начинается после эпидемии 1871 г. В 70-е гг. основным механизмом обеспечения санитарного контроля в городе стало издание и контроль за исполнением обязательных постановлений городской Думы. Достижением городских органов общественного управления в этот период можно считать создание в городе водопровода. В 70-х гг. XIX века водопровод был проведен в 37 городах Российской империи (Васильев, Сегал 1960: 218), и Кострома оказалась одним из первых российских городов, где действовал этот объект коммунальной городской инфраструктуры.

В 80-90-е гг. XIX в. нормотворческая деятельность Городской Думы оставалась важным направлением работы, изданные ранее постановления дополнялись и уточнялись, расширяя круг лиц, участвующих в деле санитарного контроля. В этот период усилился контроль за продуктами питания. Вне зависимости от эпидемий в смету городского управления по разделу «Благоустройство» начинают вноситься статьи расходов: на ремонт водопроводных труб в ватер-клозетах, очистку ретирадных мест и помойных ям, ремонт и замощение мостовых, прокладку сточных труб для спуска вод с фабрик и заводов и др. К началу XX в. раздел сметы «Благоустройство» расширился за счет содержания городских свалок нечистот, ассенизационного и рабочего обозов. На постоянной основе стала проводиться работа по благоустройству городского пространства в виде устройства новых скверов, содержания бульваров, высаживания деревьев и цветов, устройство скамеек для горожан и др.

Одним из важных показателей эффективности деятельности городского общественного управления, на наш взгляд, можно считать процент смертности населения Костромской губернии. Если в 1876 г. средний показатель смертности по Европейской России составлял 32,5\%, то в Костромской губернии - 39,4\% (Отчет Костромской Городской Управы1901: 3). К 1914 г. средний показатель по европейской России составлял 26,7\%, а в Костромской губернии - 27,8\% (Отчет о состоянии народного здравия 1913: 2-4). Несмотря на то, что в Костромской губернии смертность незначительно, но была выше, чем в среднем по европейской России, данный показатель за исследуемый период снижается.

Проводя аналогии с сегодняшним днем, можно заключить, что эффективность борьбы с эпидемиями зависит от множества факторов. Но ключевым принципом профилактики должно быть согласованное взаимодействие медицинских 
учреждений, органов управления, частных и государственных организаций, предприятий, и в немалой степени, частных лиц. Комплекс мероприятий, информирование граждан и координирующие усилия властей будут способствовать успешной борьбе с эпидемиями.

\section{Источники и материалы}

Айвазов 1913 - Айвазов И.Г. Законодательство по церковным делам в царствование Император Александра III-го. М.: Печатня А.И. Снегиревой, 1913. 222 с.

Архангельский 1871a - Архангельский Г.И. Эпидемия холеры в России летом 1871-го года// Эпидемиологический листок. - 1871а. № 6. С. 10-13.

Архангельский $1871 \mathrm{~b}$ - Архангельский Г.И. Обзор холерной эпидемии в России в 1871 году по 1 августа // Эпидемиологический листок. 1871b. № 7. С.17-20.

Варадинов 1855 - Варадинов Н.В. История Министерства внутренних дел: в 3 ч. Ч. 3., кн. 3: Период третий: с 19 ноября 1825 по 20 августа 1855. СПб.: тип. МВД 1862. 725 с.

Городовое положение 1870 - Высочайше утвержденное 16 июня 1870 года Городовое положение с объяснениями. СПб.: типография МВД, 1870. 239 с.

Иванов 1883 - Иванов И.С. Движение населения Костромской губернии в 1880 году и причины смертности. Кострома: губернская типография, 1883. 699 с.

Иванов 1885 - Иванов И.С. Холерные эпидемии в Костромской губернии с 1830 по 1871 г./ Приложение к Губернским ведомостям, Кострома: губернская типография, 1885. 46 c.

Костромские 81871 - Костромские Губернские Ведомости 1871. № 8

Костромские 271871 - Костромские Губернские Ведомости 1871. № 27

Костромские 341871 - Костромские Губернские Ведомости, 1871. № 34

Костромские 351871 - Костромские Губернские Ведомости, 1871. № 35

Материалы для статистики 1870 - Материалы для статистики Костромской губернии. Издание Костромского Губернского Статистического Комитета // Под ред. В. Пирогова. Выпуск первый. Кострома: губернская типография, 1870. 97, 63, 19 с.

Материалы для статистики 1881 - Материалы для статистики Костромской губернии. Издание Костромского Губернского Статистического Комитета // Под ред. В. Пирогова. Выпуск четвертый. - Кострома: губернская типография. 1881. 303, 59 с.

Обзор 1871 - Обзор Костромской губернии за 1870 год: приложение ко всеподданнейшему отчету Костромского губернатора. Кострома, 1871. 97 с.

Обзор 1872 - Обзор Костромской губернии за 1871 год: приложение ко всеподданнейшему отчету Костромского губернатора. Кострома, 1872. 95 с.

Обзор 1880 - Обзор Костромской губернии за 1879 год: приложение ко всеподданнейшему отчету Костромского губернатора. Кострома, 1880. 47 с.

Обзор 1881 - Обзор Костромской губернии за 1880 год: приложение ко всеподданнейшему отчету Костромского губернатора. Кострома. 1881. 53 с.

Обзор 1885 - Обзор Костромской губернии за 1884 год: приложение ко всеподданнейшему отчету Костромского губернатора. Кострома. 1885. 2, 30, 36 с.

Обзор 1889 - Обзор Костромской губернии за 1888 год: приложение ко всеподданейшему отчету Костромского губернатора. Кострома. 1889. 2, 26, 31 с.

Обзор 1893 - Обзор Костромской губернии за 1892 год: приложение ко всеподданейшему отчету Костромского губернатора. Кострома. 1893. 2, 30 с.

Обзор 1894 - Обзор Костромской губернии за 1893 год: приложение ко всеподданейшему отчету Костромского губернатора. Кострома. 1894. 2, 30, 45 с.

Обзор 1895 - Обзор Костромской губернии за 1894 год: приложение ко всеподданейшему отчету Костромского губернатора. Кострома. 1895. 2, 32, 43 с.

Обзор 1901 - Обзор Костромской губернии за 1900 год: Приложение ко всеподданейшему отчету Костромского губернатора. Кострома. 1901. 2, 36, 31 с. 
Обзор 1908 - Обзор Костромской губернии за 1907 год: Приложение ко всеподданейшему отчету Костромского губернатора. Кострома. 1908 2, 72, 34 с.

Обзор 1911 - Обзор Костромской губернии за 1910 год: Приложение ко всеподданейшему отчету Костромского губернатора. Кострома. 1911. 2, 54, 26 с.

Обзор 1914 - Обзор Костромской губернии за 1913 год: Приложение ко всеподданейшему отчету Костромского губернатора. Кострома. 1914 2, 66, 36 с.

Обзор 1915 - Обзор Костромской губернии за 1914 год: Приложение ко всеподданейшему отчету Костромского губернатора. Кострома. 1915. 2, 66, 36 с.

Обязательные постановления Вып.1 1897 - Обязательные постановления Костромской Городской Думы для жителей города Костромы изданные в разное время в установленном законом порядке: в 2 т. Кострома: губернская типография, 1897. Вып. 1. - 50 с.

Обязательные постановления Вып.2 1897 - Обязательные постановления Костромской Городской Думы для жителей города Костромы изданные в разное время в установленном законом порядке: в 2 т. Кострома: губернская типография, 1897. Вып. 2.32 с.

Островский 1864 - Островский П.Ф. Исторические записки о Костроме и ее святыне, благочестно-чтимой в императорском доме Романовых. Кострома: типография Андроникова, $1864.245 \mathrm{c}$.

Отчет Управы 1899 - Отчет Костромской Городской Управы за 1898 год. Кострома: губернская типография, 1899. 198 с.

Отчет Управы 1900 - Отчет Костромской Городской Управы за 1899 год. Кострома: губернская типография, 1900. - 254 с.

Отчет Управы 1901 - Отчет Костромской Городской Управы за 1900 год. Кострома: губернская типография, 1901. 364 с.

Отчет Мед. департамента 1877 - Отчет Медицинского департамента за 1876 год, представленный Его Высокопревосходительству Господину Министру внутренних дел, СПб: типография Стасюлевича. 1877. 104 с.

Отчет Мед. департамента 1878 - Отчет Медицинского департамента за 1877 год, представленный Его Высокопревосходительству Управляющему Министерством внутренних дел, СПб: типография Стасюлевича. 1878. -217 с.

Отчет Мед. департамента 1881 - Отчет Медицинского департамента за 1879 год, представленный Его Сиятельству Господину Министру внутренних дел, СПб: типография МВД. $1881.407 \mathrm{c}$.

Отчет Мед. департамента 1882 - Отчет Медицинского департамента за 1880 год. Представленный Его Сиятельству Министру Внутренних дел. СПб: типография МВД, 1882. 517 с.

Отчет Мед. департамента 1886 - Отчет Медицинского департамента за 1883 год. Часть медицинская. СПб: типография МВД, 1886, 546 с.

Отчет Мед. департамента 1877 - Отчет Медицинского департамента за 1886 год. Часть медицинская. СПб: типография Министерства внутренних дел, 1888. - IV, 405 с.

Отчет Мед. департамента 1884 - Отчет Медицинского департамента Министерства внутренних дел за 1881 год. СПб: типография МВД, 1884. - 619 с.

Отчет Мед. департамента 1885 - Отчет Медицинского департамента Министерства внутренних дел за 1882 год. СПб: типография МВД, 1885. - 803 с.

Отчет Мед. департамента 1887 - Отчет Медицинского департамента Министерства внутренних дел за 1884 год. Часть медицинская. СПб: типография МВД, 1887. - IV, 176, 59 с.

Отчет Мед. департамента 1891 - Отчет Медицинского департамента Министерства внутренних дел за 1888 год. СПб: типография МВД, 1891. - XXII, 146, 198 с.

Отчет Мед. департамента 1894 - Отчет Медицинского департамента Министерства внутренних дел за 1891 год, СПб: типография МВД, 1894. - 11, 159, 305 с.

Отчет Мед. департамента 1896 - Отчет Медицинского департамента Министерства внутренних дел за 1892 год, СПб: типография МВД, 1896. - Х, 159, 303 с.

Отчет о состоянии народного здравия 1908 - Отчет о состоянии народного здравия и ор- 
ганизации врачебной помощи в России за 1906 год / Управление Главного Врачебного Инспектора МВД. СПб: типография МВД, 1908. - с. VII, 100, 257

Отчет о состоянии народного здравия 1909 - Отчет о состоянии народного здравия и организации врачебной помощи в России за 1907 год / Управление Главного Врачебного Инспектора МВД, СПб: типография МВД, 1909. VIII, 224, 269 с.

Отчет о состоянии народного здравия 1910 - Отчет о состоянии народного здравия и организации врачебной помощи в России за 1908 год / Управление Главного Врачебного Инспектора МВД, СПб: типография МВД, 1910. 273 с.

Отчет о состоянии народного здравия 1912 - Отчет о состоянии народного здравия и организации врачебной помощи в России за 1910 год / Управление Главного Врачебного Инспектора МВД, СПб: типография МВД, 1912. - IX, 112, 269 с.

Отчет о состоянии народного здравия 1913 Отчет о состоянии народного здравия и организации врачебной помощи в России за 1911 год/Управление Главного Врачебного Инспектора МВД. - СПб: типография МВД, 1913. IX, 84, 339 с.

Отчет о состоянии народного здравия 1916 - Отчет о состоянии народного здравия и организации врачебной помощи в России за 1914 год / Управление Главного Врачебного Инспектора МВД. Петроград: типография МВД, 1916. - VIII, 63, 211 с.

Полное собрание законов 1852 - Полное собрание законов Российской империи. Т. 27 (1852). Ч.2. Дополнение к 27 тому. № 25930 а. Режим доступа: http://nlr.ru/e-res/law_r/search. php?part $=601 \&$ regim $=3(23.07 .2020)$

Церковные Ведомости 1889 - Церковные Ведомости, издаваемые при Святейшем Правительствующем Синоде. 1889. №32

\section{Научная литература}

Белов А.М. (отв. ред., сост.) Служение отечеству. Руководители Костромской губернии и области, 1778-2009 гг.: ист.-биогр. очерки. Кострома: КГУ им. Н.А. Некрасова, 2009. 296 с.

Васильев К.Г. Сегал А.Е. История эпидемий в России (материалы и очерки). М.: Государственное издательство медицинской литературы, 1960. 397 с.

Кучер Т.Я. (сост.) 125 лет Костромскому водоканалу. Кострома: ИПП «Кострома», 1996. 338 с.

Рашин А.Г. Население России за 100 лет (1811-1913 гг.). Статистические очерки / под редакцией академика С.Г. Струмилина. М.: Государственное статистическое издательство, 1956. $351 \mathrm{c}$.

Belov, A.M, Galinskaya O.Yu.*

\section{The activities of local authorities to combat epidemics in the second half of the XIX - early XX century (based on the materials of the Kostroma province)}

\section{DOI: $10.33876 / 2311-0546 / 2021-54-2 / 128-143$}

After the peasant reform of 1861, the growth of the urban population in Kostroma led to the problems of overpopulation in the provincial center. The existing infrastructure did not match (housing, transport, utilities) the changed population. This contributed to the sharp growth and spread of infectious diseases among the population of Kostroma, including massive epidemics of cholera, typhoid, smallpox, scarlet fever. The result was an increased mortality rate among the population. The article, based on materials Kostroma province, primarily the provincial center, examines the general epidemiological situation from the 70s of the 19 th century to the beginning of the 20th century. The main directions of joint activities of the provincial government and city public administration bodies to reduce epidemiological tension and prevent mass diseases during the period of modernization are investigated. The article provides statistical data on the Kostroma province and the provincial center, uses 
the reports of the Medical Department of the Ministry of Internal Affairs for the specified period, materials from periodicals, shows the regional specifics of solving the problems that have arisen, given that the Kostroma province was one of the most developed industrial provinces of the Russian Empire.

Keywords: mass epidemics, epidemiological situation, Kostroma province, mortality, provincial government, public administration, statistics

For Citation: Belov, A.M, Galinskaya O.Yu. 2021. The activities of local authorities to combat epidemics in the second half of the XIX - early XX century (based on the materials of the Kostroma province). Herald of Antropology (Vestnik Antropologii) 2: 128-143.

\section{Author Info:}

Belov, Andrey M. - Doctor of Hist., Professor, Kostroma State University (Kostroma, Russia). E-mail: belovi_1957@mail.ru

Galinskaya, Oksana Yu. - PhD student, Kostroma State University (Kostroma, Russia). E-mail: oknikitina@yandex.ru

Funding: The work was carried out with the financial support of the RFBR grant No. 21011-31820, supervisor A.M. Belov

\section{References}

Belov A.M. (ed.) 2009. Sluzhenie otechestvu. Rukovoditeli Kostromskoi gubernii i oblasti, 17782009 gg.: ist.-biogr. ocherki [Serving the Fatherland. Leaders of the Kostroma province and region, 1778-2009: ist.-biogr. Essays]. Kostroma: N.A. Nekrasov, KSU.

Kucher, T.Ya. (ed.). 1996. 125 let Kostromskomu vodokanalu [125 years of the Kostroma water utility]. Kostroma: IPP “Kostroma”.

Rashin, A.G. Naselenie Rossii za 100 let (1811-1913 gg.). Statisticheskie ocherki [The population of Russia for 100 years (1811-1913). Statistical essays], edited by academician S. G. Strumilin. Moscow: State Statistical Publishing House, 1956. 351 p.

Vasiliev, K.G. and A.E. Segal. 1960. Istoriia epidemii v Rossii (materialy i ocherki) [History of epidemics in Russia (materials and essays)]. Moscow: Gosudarstvennoe izdatel'stvo meditsinskoi literatury [State Publishing House of Medical Literature]. 